\title{
PERANCANGAN SISTEM INFORMASI PENGELOLAAN JASA PERCETAKAN AGNA ADVERTISING BERBASIS WEB
}

\author{
Agna Rahmah Harsinta ${ }^{1}$, Sri Rezeki Candra Nursari² \\ 'Prodi Teknik Informatika, Fak. Teknik, Universitas Pancasila \\ ${ }^{2}$ Prodi Teknik Informatika, Fak. Teknik, Universitas Pancasila \\ Jl. Srengseng Sawah Jagakarsa Jakarta 12640 \\ agnarharsinta@gmail.com,sri.rezeki.candra.n@univpancasila.ac.id
}

\begin{abstract}
Business is all activities and businesses for profit by providing goods and services needed for the economic system. In this current era, the development of online business is increasing, a variety of products are increasingly easy to buy online. The increasing number of users of this online business cannot be separated from the development of technology. Today's internet technology has developed very rapidly. The existence of the internet can support the maximum expected goals, can save costs, manpower and operational time of the company as a means of communication, publications, as well as a means to obtain various information widely. Agna Advertising is an entrepreneurial business which is engaged in printing. Agna Advertising business often experiences many constraints in its business processes, namely: Frequent overlapping of customer order data where the customer makes an order first, the order is processed later, there is often a mismatch of the customer's order product with the product received by the customer, the number of complaints from customers regarding late delivery of products to customers, as well as many customer complaints about the total error of payment that must be paid by the customer. With these various problems, an information system is needed to manage data in Agna Advertising company. The research method used is a data collection method consisting of interviews and observations while the system development method used is the SDLC Waterfall model which consists of four stages, namely analysis, design, coding, and testing. The results of testing the system using Black Box testing to show that the system is running in accordance with the expected results. The result is a web-based printing service management information system that can reduce the occurrence of complaints from customers and can facilitate companies in managing data, searching data, and making reports.
\end{abstract}

Keywords: Printing Services, Information Systems, Web-Based.

\section{PENDAHULUAN}

Bisnis (bussines) adalah seluruh aktivitas dan usahauntuk mencari keuntungan dengan menyediakan barang dan jasa yang dibutuhkan bagi sistem perekonomian, beberapa bisnis memproduksi barang berwujud sedangkan yang lain memberikan jasa[1].

Di era sekarang ini, perkembangan bisnis online semakin meningkat, beragam produk sudah semakin mudah di beli secara online mulai dari hasil produksi rumahan, produk furneture, dan lain sebagainya. Semakin mengingkatnya pengguna bisnis online ini tidak bisa terlepas dari semakin berkembang nya teknologi.

Teknologi internet saat ini telah berkembang sangat pesat. Hal ini menyebabkan terjadinya perubahan yang tidak bisa kita hindari sehingga dituntut untuk bisa mengikuti perkembangan teknologi yang ada. Adanya internet dapat menunjang tujuan maksimal yang diharapkan, dapat menghemat biaya, tenaga dan waktu operasional perusahaan sebagai sarana komunikasi, publikasi, serta sarana untuk mendapatkan berbagai informasi secara luas.

Percetakan (printing) adalah sebuah proses memproduksi tulisan maupun gambar salinan dari sebuah dokumen atau foto di atas kertas secara massal menggunakan mesin cetak [2]. Percetakan disebut juga sebagai sebuah badan usaha yang memproduksi bahan baku yang disebut dengan media cetak dengan mencetak salinan kata-kata atau gambar yang telah di setting menjadi hasil cetakan pada media cetak yang dapat memberikan informasi bagi yang menerimanya.Konsep Fuzzy Logic sangatlah sederhana dan mudah dipahami.

Agna Advertising merupakan usaha yang bergerak dalam bidang percetakan, letaknya didaerah Citeureup, kab. Bogor. Agna Advertising menawarkan jasa percetakan seperti pembuatan brosur, benner, kartu nama, undangan, kaos partai, dan lain sebagainya. Usaha Agna Advertising sering mengalami kendala dalam proses bisnisnya, yaitu sering terjadinya tumpang tindih data pemesanan pelanggan yang mana pelanggan yang melakukan pemesanan terlebih dahulu justru pemesanannya diproses belakangan, sering terjadi juga ketidak sesuaian produk pemesanan pelanggan dengan produk yang diterima oleh pelanggan, banyaknya complain dari pelanggan mengenai keterlambatan pengiriman produk ke pelanggan, serta banyak pula complain pelanggan mengenai kesalahan total pembayaran yang harus dilunasi oleh pelanggan.

Dengan adanya berbagai masalah tersebut maka diperlukannya sebuah tahapan yang dapat membantu dalam 
pembuatan sebuah sistem informasi, tahapan-tahapan tersebut meliputi tahapan pengumpulan data dan tahapan pengolahan data.

Salah satu tahapan pengumpulan data adalah dengan cara melakukan wawancara dan observasi [3]. Sedangkan tahap pengolahan data dilakukan dengan menggunakan metode Software Development Life Cycle (SDLS). SDLC sendiri memiliki arti suatu pendekatan yang sistematis dan berurutan (skuensial) pada pengembangan perangkat lunak, salah satu metode yang ada pada SDLC yaitu metode SDLC Waterfall. Metode SDLC Waterfall merupakan metode pengembangan perangkat lunak dengan tahapan yang berurutan pada proses pengerjaannya sehingga digambarkan terus mengalir ke bawah seperti air terjun [4].

Selain kedua tahapan diatas, dalam membuat sebuah sistem juga diperlukan adanya tahapan pengujian yang bertujuan untuk memastikan apakah semua fungsi sistem bekerja dengan baik dan untuk menemukan kesalahan-kesalahan atau kekurangan-kekurangan yang terjadi pada perangkat lunak yang diuji, pada tahap ini, penulis melakukan pengujian dengan metode black box testing.

Dari penjelasan diatas penulis memberikan kesimpulan untuk masalah di Agna Advertising dapat terbantu dengan adanya sistem informasi berbasis web yang dapat mendukung aktifitas perusahaan.

\section{LANDASAN TEORI}

\section{A. Kajian Teori}

1. Sistem Informasi

Sistem adalah suatu jaringan kerja dari prosedur-prosedur yang saling berhubungan, berkumpul bersama-sama untuk melakukan suatu kegiatan atau untuk menyelesaikan suatu sasaran yang tertentu. Informasi adalah data yang diolah menjadi bentuk yang lebih berguna bagi yang menerimanya[5]. Sistem informasi adalah alat untuk menyajikan informasi sedemikian rupa sehingga bermanfaat bagi penerimanya. Tujuannya adalah untuk memberikan informasi dalam perencanaan, memulai, pengorganisasian, operasional sebuah perusahaan yang melayani sinergi organisasi dalam proses mengendalikan pengambilan keputusan[6].

\section{Adversiting}

Advertising adalah suatu usah yang bergerak dibidang periklanan, advertising tidak bisa lepas dari yang namanya ide karena untuk membuat iklan membutuhkan ide yang bagus dan kreatif. Advertising juga menyediakan jasa untuk membuat konsep, percetakan, maupun penempatan iklan.

Hal ini tergantung jenis usaha dari advertising karena seiring berkembangnya dunia usaha atau bisnis, advertising dapat menjadi alternatif bagi usaha, karena hampir semua perusahaan yang akan menjual produk ataupun jasanya membutuhkan advertising.

\section{Percetakan}

Percetakan adalah sebuah proses industri untuk memproduksi massal tulisan dan gambar, terutama dengan tinta di atas kertas menggunakan sebuah mesin cetak. Percetakan merupakan bagian penting dalam penerbitan dan percetakan transaksi. Teknik percetakan umum lainnya termasuk cetak relief, sablon, rotogravure, dan percetakan berbasis digital seperti pita jarum, inkjet, dan laser. Dikenal pula teknik cetak poly untuk pemberian kesan emas dan perak ke atas permukaan dan cetak emboss untuk memberikan kesan menonjol kepada kertas[7].

4. Jasa

Jasa adalah setiap tindakan atau perbuatan yang dapat ditawarkan oleh satu pihak kepada pihak lain yang pada dasarnya tidak berwujud (intangible) dan tidak menghasilkan kepemilikan apapun[8].

\section{Pemesanan}

Pemesanan adalah Proses pembelian suatu barang atau jasa yang dilakukan oleh konsumen kepada penjual sebelum konsumen mendapatkan barang. Langkah pemesanan yang paling sderhana adalah dengan melakukan kontak langsung kepada penjual kemudian konsumen memesan barang atau jasa yang diinginkan. Pemesanan barang atau jasa saat ini bisa dilakukan dengan berbagai cara, baik secara lisan maupun dengan dunia maya.

6. Pengiriman

Pengiriman adalah bagian penting dalam suatu proses bisnis, yang berfungsi untuk menyiapkan dan mengirimkan barang ke konsumen, dan berhubungan dengan model transportasi apa yang digunakan agar efektif dan efisien, baik dari sisi biaya, kecepatan waktu pengiriman, dan ketepatan waktu[9].

\section{METODE PENELITIAN}

Dalam Penelitian biasanya dilakukan menggunakan dua metode, yaitu metode pengumpulan data dan metode pengembangan system.

A. Tahapan Pengumpulan Data

Tahapan ini menggunakan metode wawancara (mengunjungi toko Agna Advertising untuk melakukan tanya jawab dengan pemilik perusahaan secara langsung tentang informasi yang dibutuhkan) dan observasi (mengamati proses kerja dan permasalahan uang terjadi pada perusahaan Agna Advertising).

\section{B. Tahapan Pengelolaan Data}

Sistem informasi Pengelolaan jasa percetakan yang dibuat ini berdasarkan metode SDLC (Software Development Life Cycle). Salah satu metode yang ada pada SDLC yaitu metode SDLC Waterfall. Tahapan metode Waterfall yaitu analisa, desain, pengodean, dan pengujian yang diilustrasikan pada gambar 1 . 


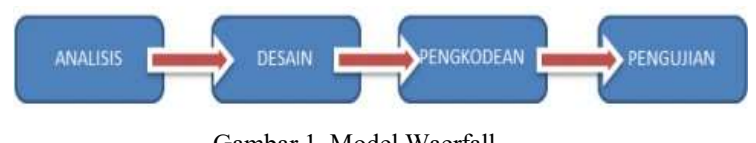

Gambar 1. Model Waerfall

Metode Waterfall memiliki langkah yaitu : analisis, desaian, pengkodean dan pengujian.

Blackbox tesing merupakan teknik pengujian sistem yang bertujuan untuk memastikan apakah semua fungsi sistem bekerja dengan baik dan untuk menemukan kesalahan-kesalahan atau kekurangan-kekurangan yang terjadi pada perangkat lunak yang diuji, dengan menggunakan metode blackbox testing ini temuan kesalahan dapat di minimalisir dan sistem yang di hasilkan akan menjadi lebih baik.

\section{HASIL DAN PEMBAHASAN}

Pada tahap ini membahas perancangan Sistem Informasi Pengelolaan Jasa Percetakan Agna Advertising berbasis web mulai dari pemodelan sistem sampai implementasi.

A. Pemodelan Sistem

1. Usecase Diagram Admin

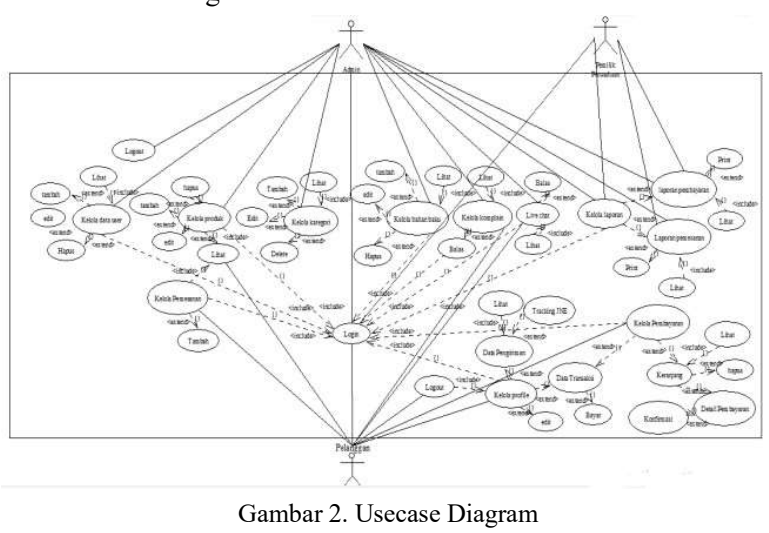

2. Acticity Diagram

a. Activity Diagram Daftar Pelanggan

Pada gambar 3 menjelaskan aliran aktivitas daftar pelanggan. Jika data yang dimasukan sudah lengkap maka pelanggan akan diarahkan ke halaman utama aplikasi.

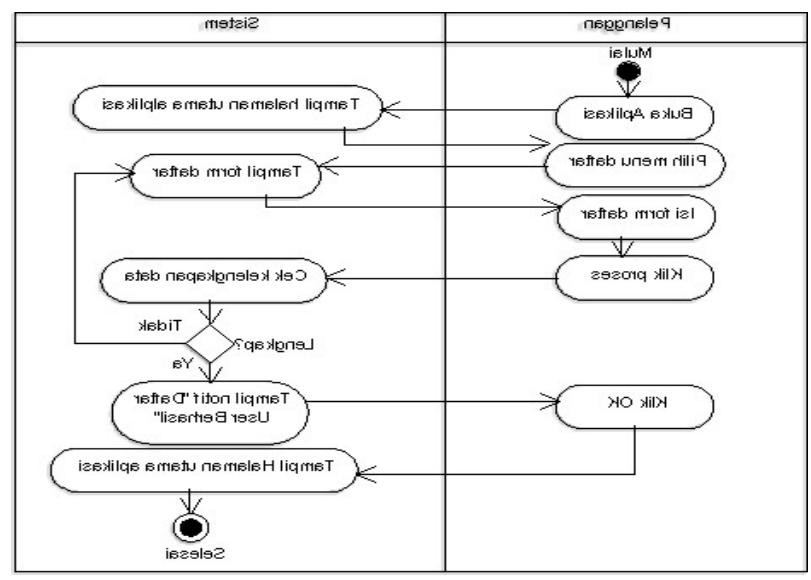

Gambar 3. Activity Diagram Daftar Pelanggan

b. Activity Diagram Login Pelanggan

Pada gambar 4 menjelaskan aliran aktivitas login pelanggan. Jika data yang dimasukan pelanggan valid maka akan diarahkan ke halaman utama pelanggan.

Himpunan fuzzy diperlukan untuk mempresentasekan variabel fuzzy dengan membentuk fungsi keanggotaan. Fungsi keanggotaan mendefiniskan titik-titik himpunan fuzzy ke dalam derajat keanggotaan nol sampai satu $(0,1)$ pada variabel fuzzy tertentu. Ada empat variabel input dan satu variabel output fuzzy yang direpresentasikan dalam fungsi keanggotaan, yaitu variabel suhu udara, kelembaban relatif, kecepatan angin, tekanan udara dan curah hujan dengan penjelasan sebagai berikut:

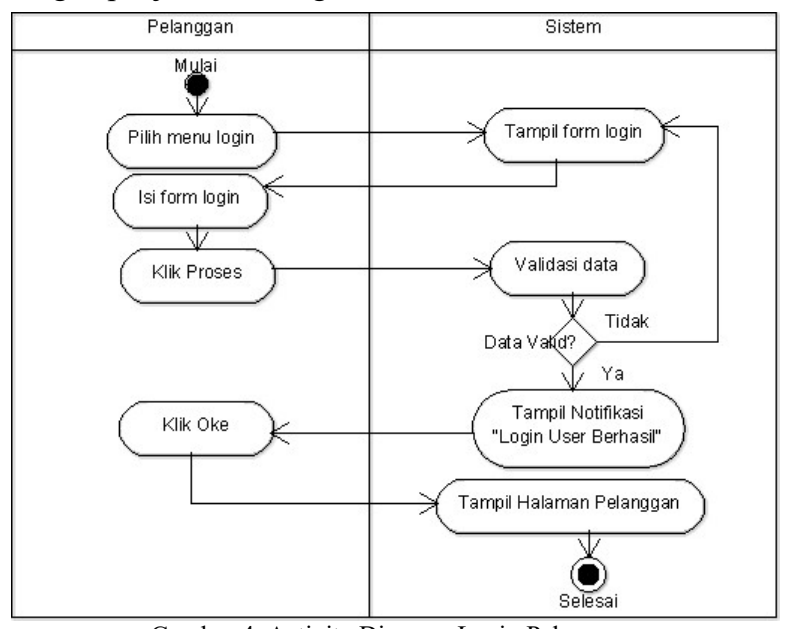

Gambar 4. Activity Diagram Login Pelanggan 
Jurnal MediaTIK : Jurnal Media Pendidikan Teknik Informatika dan Komputer

Vol.3 No.1 (Januari 2020)

65

c. Activity Diagram Pemesanan

Pada gambar 5 menjelaskan aliran aktifitas pemesanan yang dilakukan oleh pelanggan.

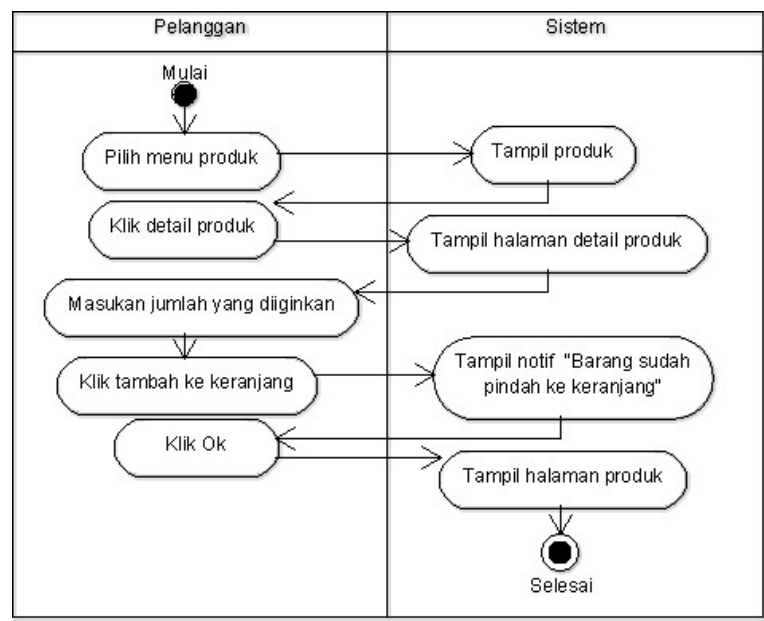

Gambar 5. Activity Diagram Pemesanan

d. Activity Diagram Konfirmasi Detail Pembayaran

Pada gambar 6 menjelaskan aliran aktifitas konfirmasi pembayaran yang dilakukan oleh pelanggan.

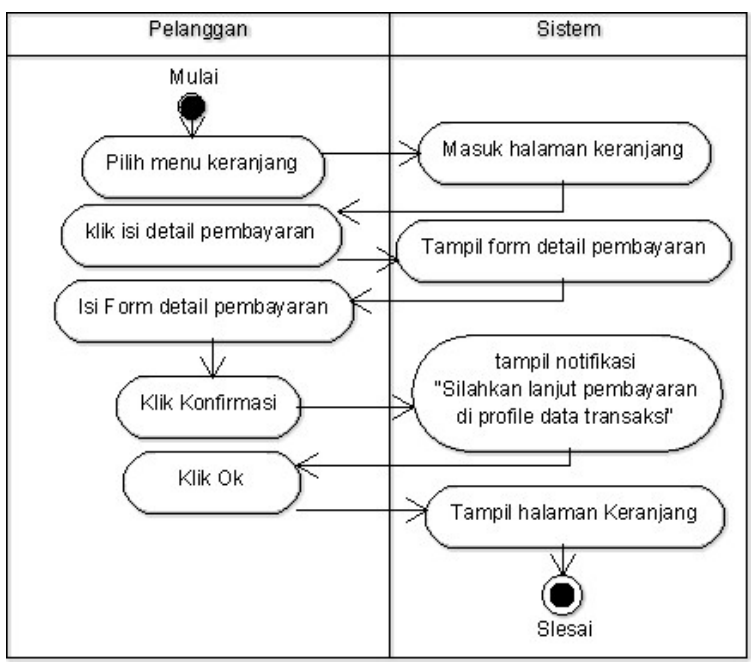

Gambar 6. Activity Diagram Detail Pembayaran e. Activity Diagram Pembayaran

Pada gambar 7 menjelaskan aliran aktifitas pembayaran yang dilakukan oleh pelanggan.

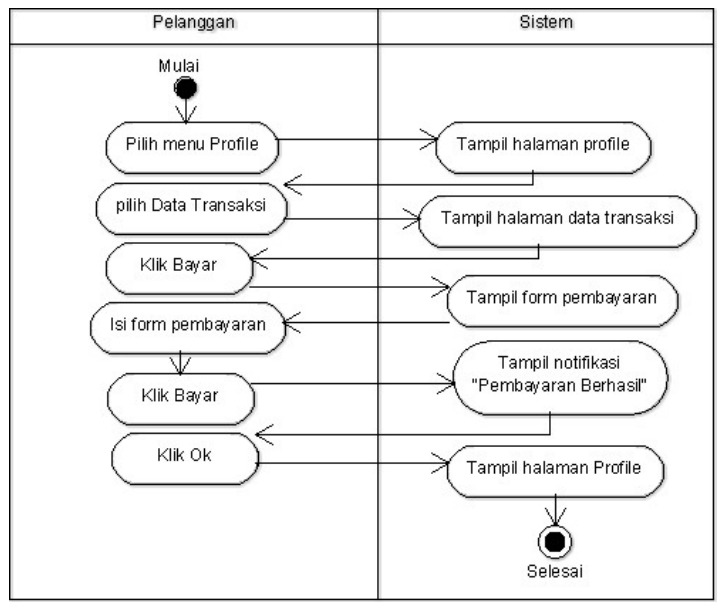

Gambar 7. Activity Diagram Pembayaran

f. Activity Diagram Kelola Keranjang

Pada gambar 8 menjelaskan aliran aktifitas kelola keranjang yang dilakukan oleh pelanggan, pelanggan dapat melakukan hapus data pada halaman keranjang.

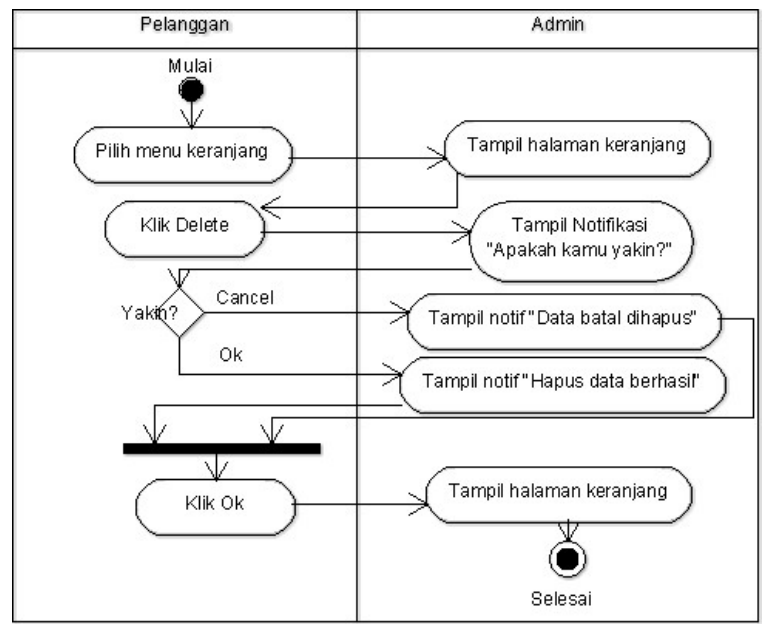

Gambar 8. Activity Diagram Keranjang 
Jurnal MediaTIK : Jurnal Media Pendidikan Teknik Informatika dan Komputer

Vol.3 No.1 (Januari 2020)

g. Activity Diagram Kelola Profil

Pada gambar 9 menjelaskan aliran aktifitas kelola profile yang dilakukan oleh pelanggan. Pelanggan dapat mengubah data password dan alamat pada form ubah profile.

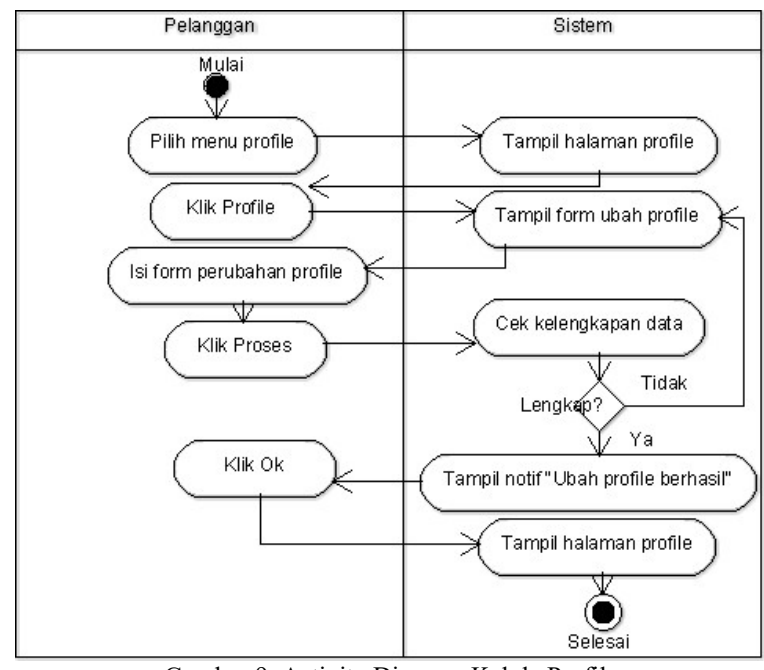

Gambar 9. Activity Diagram Kelola Profile

h. Activity Diagram Kelola Data Pengiriman

Pada gambar 10 menjelaskan aliran aktifitas kelola data pengiriman yang dilakukan oleh pelanggan. Pelanggan dapat melihat keberadaa barang yang sedang dikirim melalui situs web JNE Tracking.

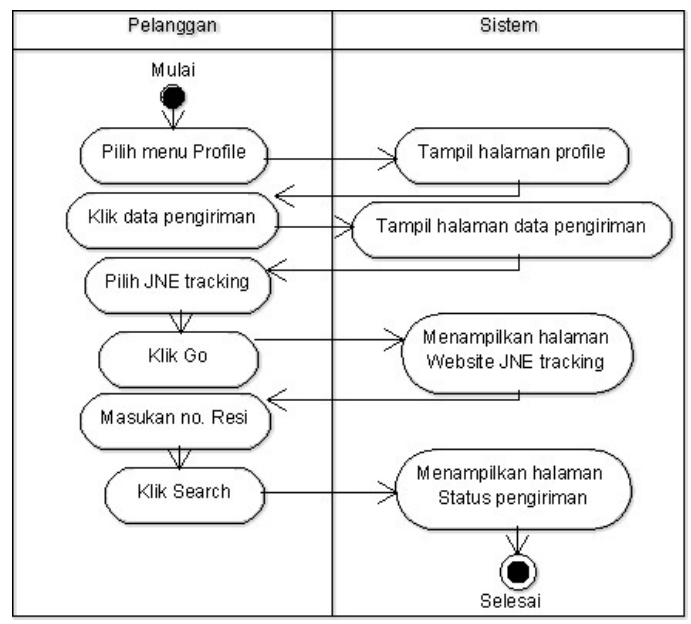

Gambar 10. Activity Diagram Kelola Data Pengiriman i. Activity Diagram Kelola Chat

Pada gambar 11 menjelaskan aliran aktifitas kelola chat yang dilakukan oleh pelanggan.

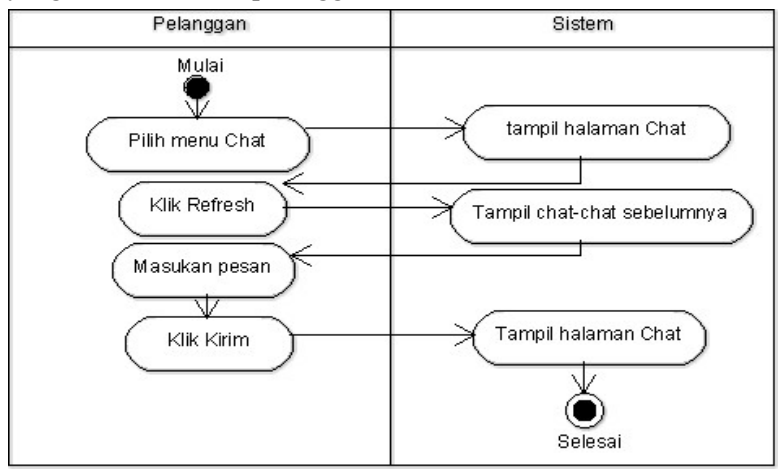

Gambar 11. Activity Diagram Kelola Chat

j. Activity Diagram Kelola Komplain

Pada gambar 12 menjelaskan aliran aktifitas kelola komplain yang dilakukan oleh pelanggan apabila ada ketidak sesuaian barang ketika barang sudah diterima.

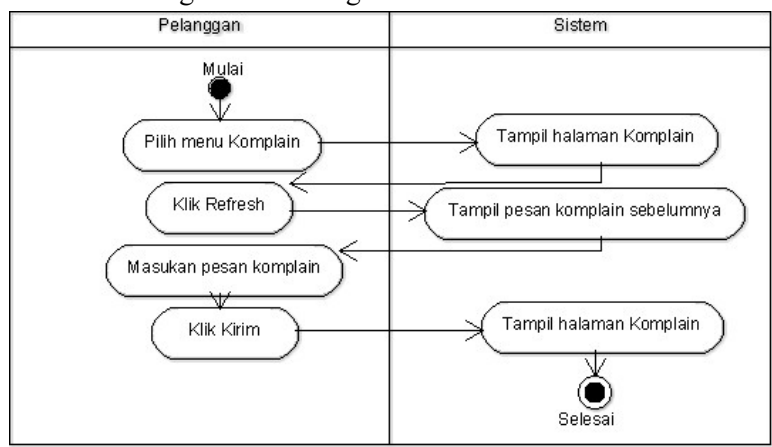

Gambar 12. Activity Diagram Kelola Komplain

k. Activity Diagram Login Admin

Pada gambar 13 menjelaskan aliran aktifitas login yang dilakukan oleh Admin. Jika data yang dimasukan valid maka akan diarahkan pada halaman utama Admin.

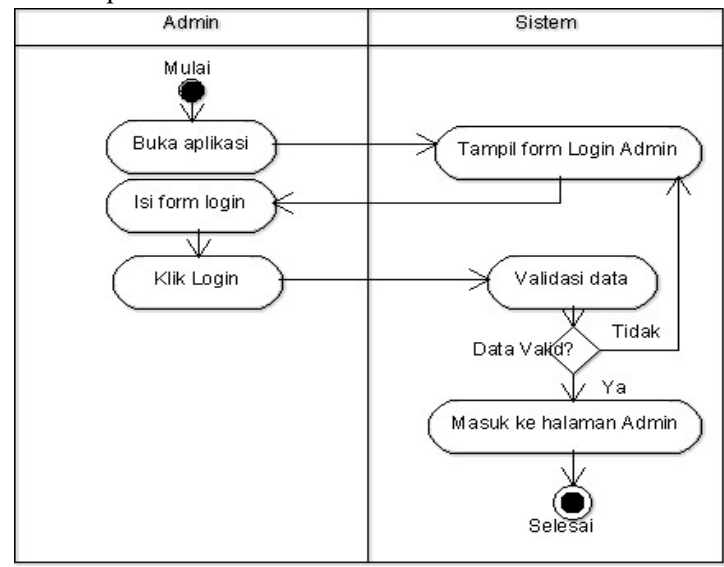

Gambar 13. Activity Diagram Login Admin 
Jurnal MediaTIK : Jurnal Media Pendidikan Teknik Informatika dan Komputer

Vol.3 No.1 (Januari 2020)

67

1. Activity Diagram Kelola User

Pada gambar 14 menjelaskan aliran aktifitas kelola user yang dilakukan oleh Admin.

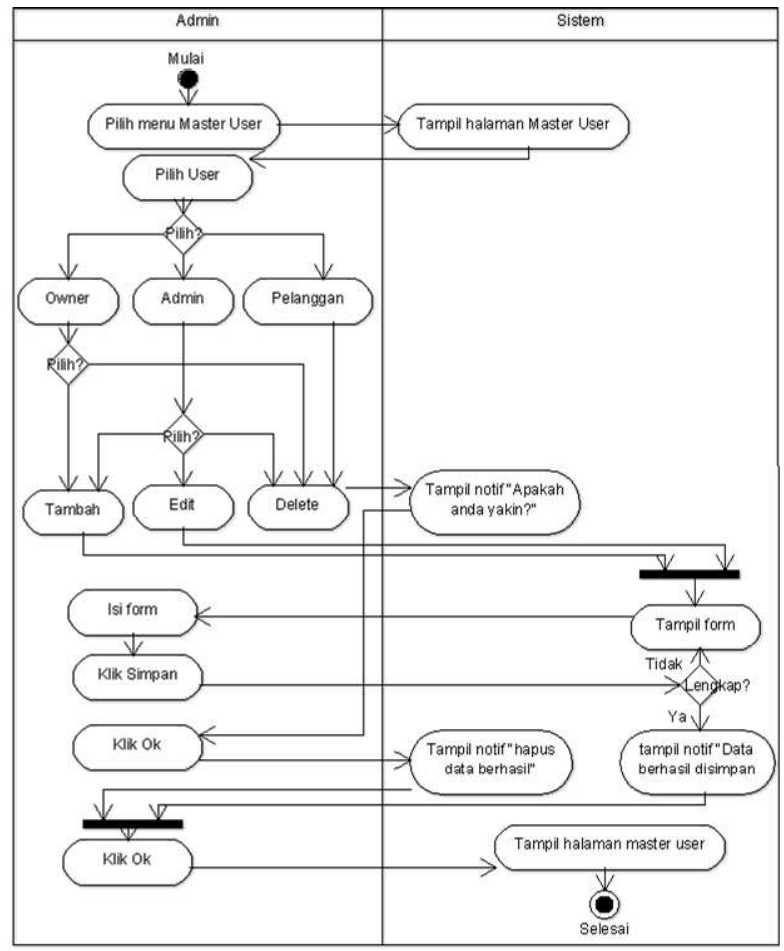

Gambar 14. Activity Diagram Kelola User

m. Activity Diagram Kelola Kategori

Pada gambar 15 menjelaskan aliran aktifitas kelola kategori yang dilakukan oleh Admin.

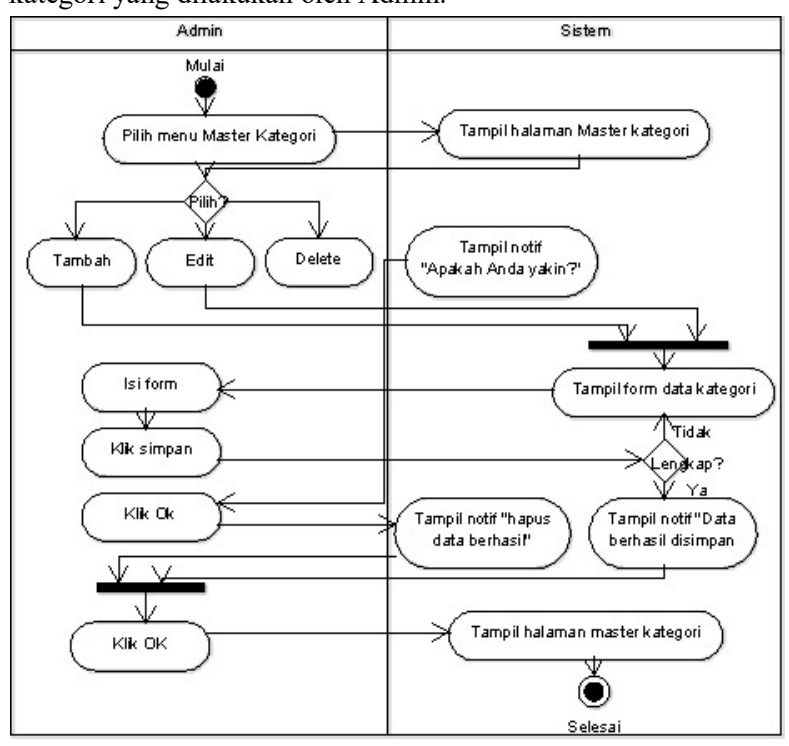

Gambar 15. Activity Diagram Kelola Kategori n. Activity Diagram Kelola Produk

Pada gambar 16 menjelaskan aliran aktifitas kelola produk yang dilakukan oleh Admin.

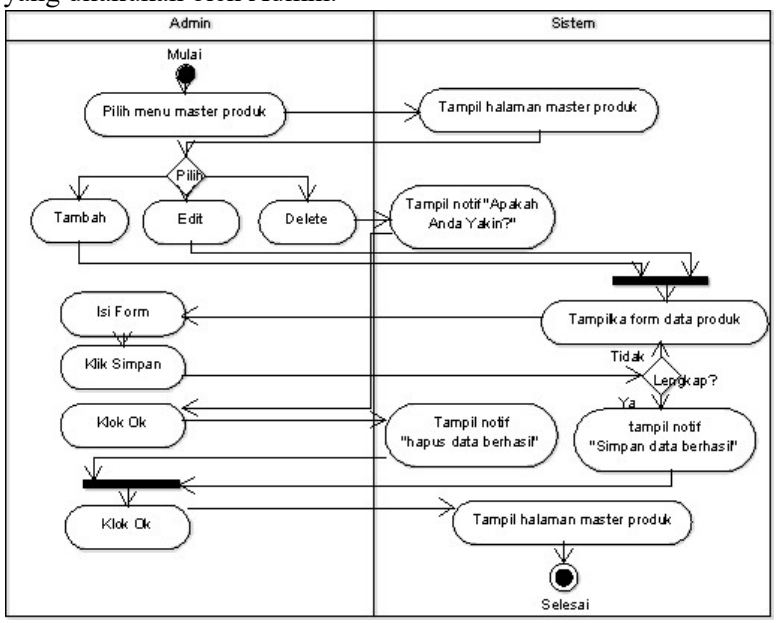

Gambar 16. Activity Diagram Kelola Produk

o. Activity Diagram Kelola Bahan Baku

Pada gambar 17 menjelaskan aliran aktifitas kelola Bahan Baku yang dilakukan oleh Admin.

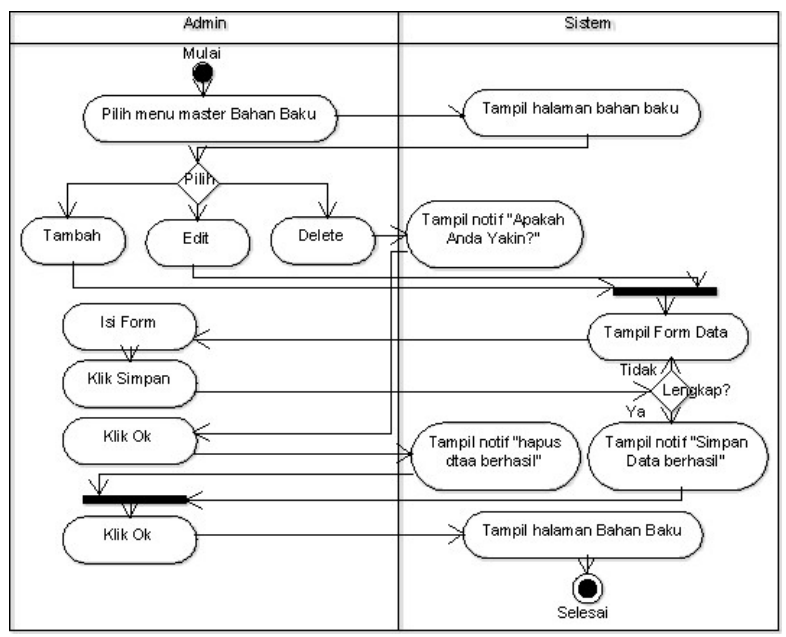

Gambar 17. Activity Diagram Kelola Bahan Baku 
Jurnal MediaTIK : Jurnal Media Pendidikan Teknik Informatika dan Komputer

Vol.3 No.1 (Januari 2020)

68

p. Activity Diagram Kelola Chat

Pada gambar 18 menjelaskan aliran aktifitas kelola chat yang dilakukan oleh Admin.

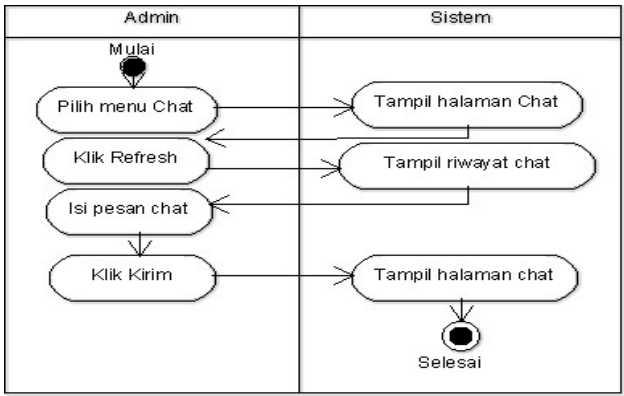

Gambar 18. Activity Diagram Kelola Chat

q. Activity Diagram Kelola Komplain

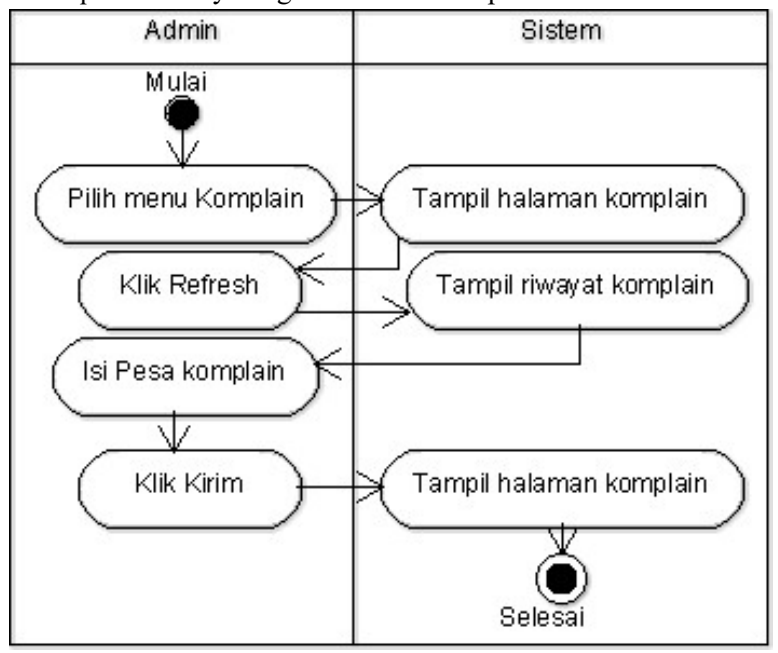

Gambar 19. Activity Diagram Kelola Komplain

r. Activity Diagram Kelola Laporan

Pada gambar 20 menjelaskan aliran aktifitas kelola laporan yang dilakukan oleh Admin.

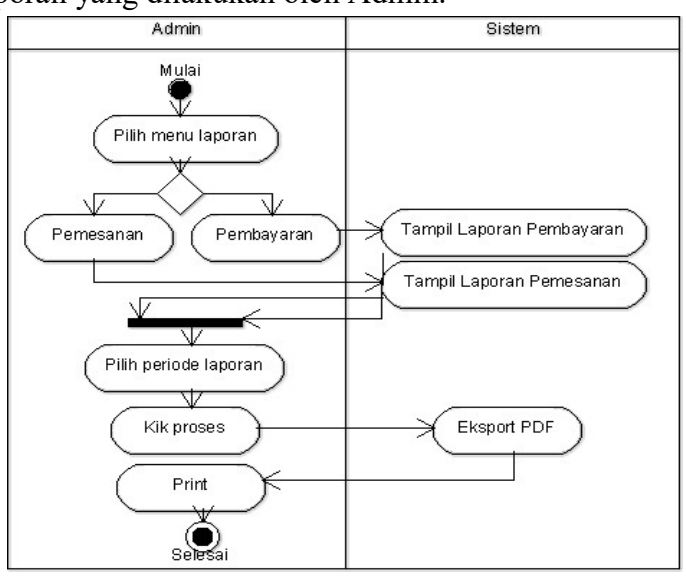

Gambar 20. Activity Diagram Kelola Laporan s. Activity Diagram Login Owner

Pada gambar 21 menjelaskan aliran aktifitas login yang dilakukan oleh Owner

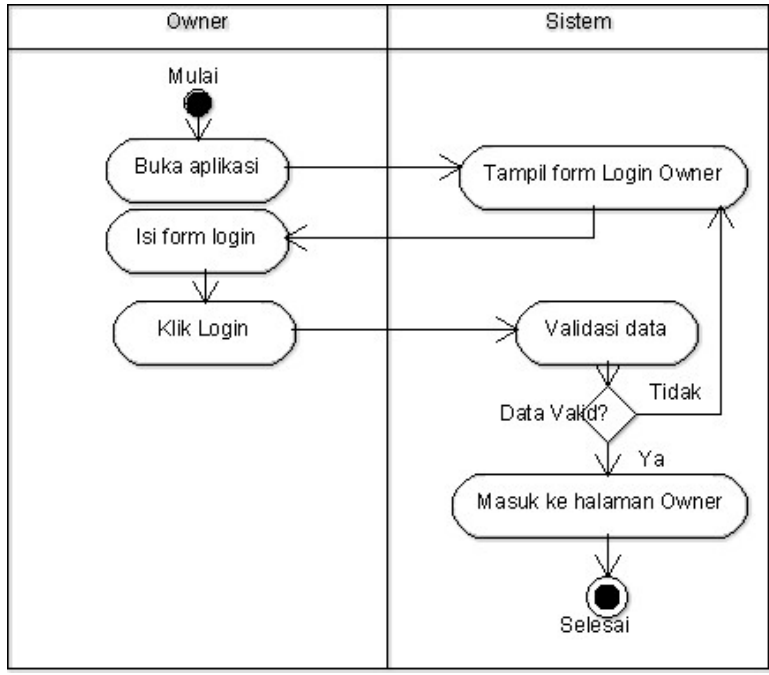

Gambar 21. Activity Diagram Login Owner

t. Activity Diagram Kelola Laporan

Pada gambar 22 menjelaskan aliran aktifitas kelola laporan yang dilakukan oleh Owner

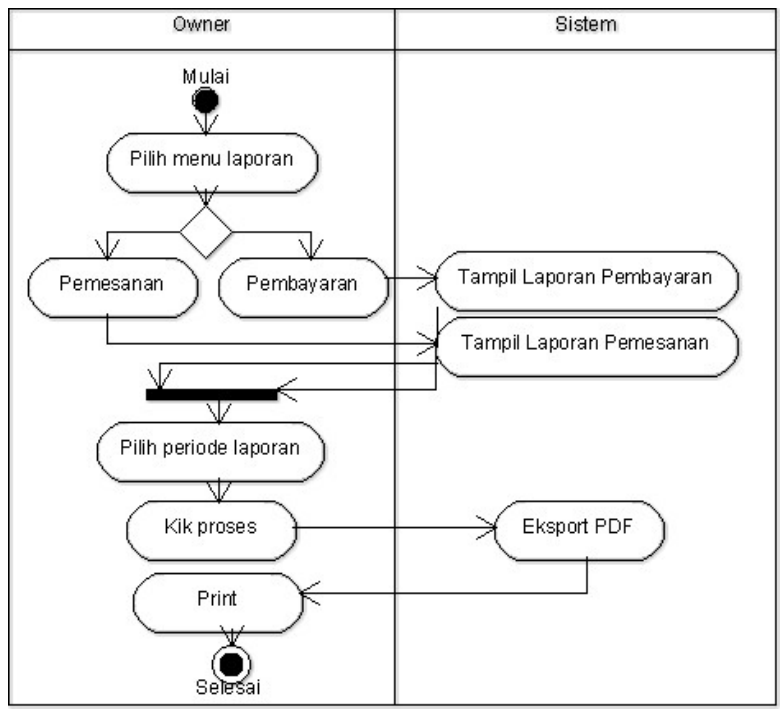

Gambar 22. Activity Diagram Kelola Laporan

3. Implementasi

a.Tampilan Halaman Login Pelanggan

Pada halaman login pelanggan terdapat form yang harus diisi untuk melakukan login yaitu username dan password yang dapat dilihat pada gambar 23 dibawah ini. 
Jurnal MediaTIK : Jurnal Media Pendidikan Teknik Informatika dan Komputer

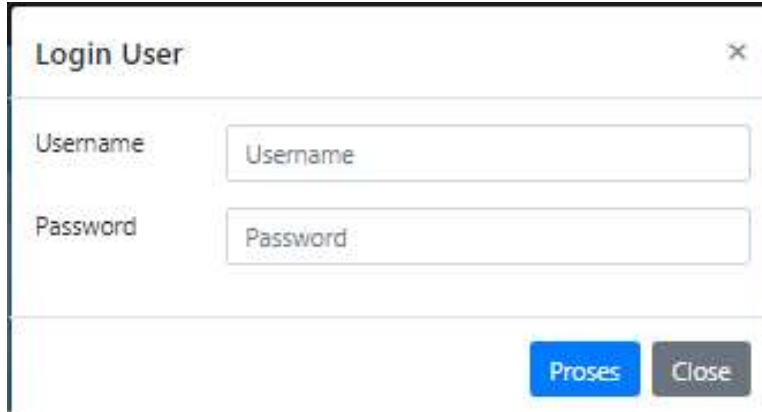

Gambar 23. Implementasi Halaman Login Pelanggan

b. Tampilan Halaman Pemesanan

Pada tampilan halaman pemsana terdapat form isian jumlah barang yang ingin dipesan seperti pada gambar 24 dibawah ini. Detail Barang

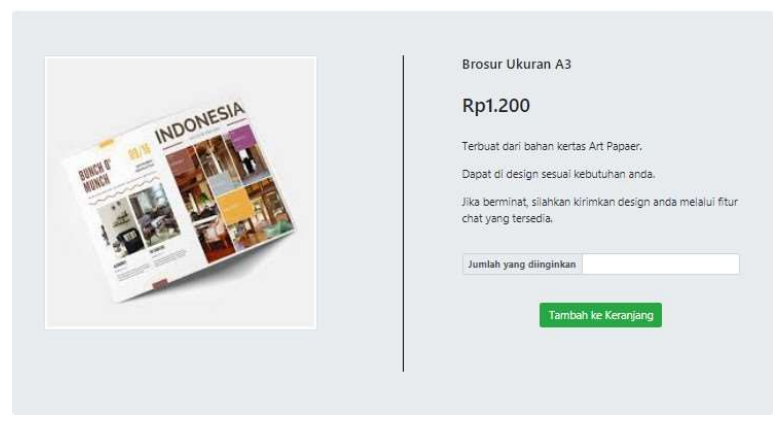

Gambar 24. Tampilan Halaman Pemesanan

c. Tampilan Halaman Pembayaran

Fitur ini diguakan untuk melakukan pembayaran oleh pelanggan, pelanggan dapat memilih jenis pembayaran yang diinginkan DP/Lunas yang dapat dilihat pada gambar 25 dibawah ini.

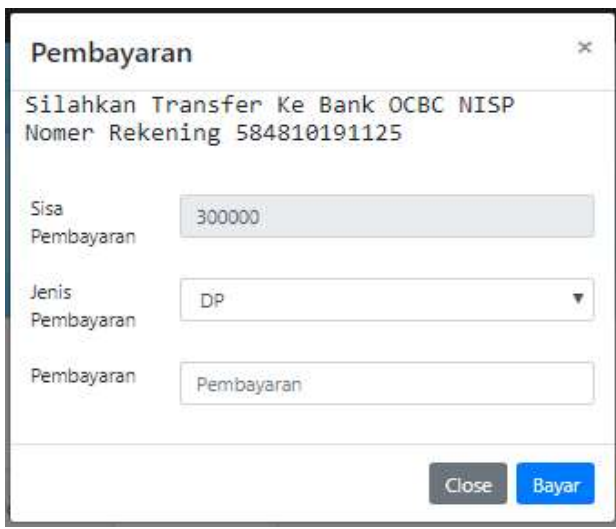

Gambar 25. Tampilan Halaman Pembayaran

\section{d. Tampilan Halaman Login Admin}

Pada halaman login admin ini terdapat form yang harus diisi dengan benar oleh admin untuk melakukan login pada system, yaitu dengan memasukan username dan password yang dapat dilihat pada gambar 26 dibawah ini.

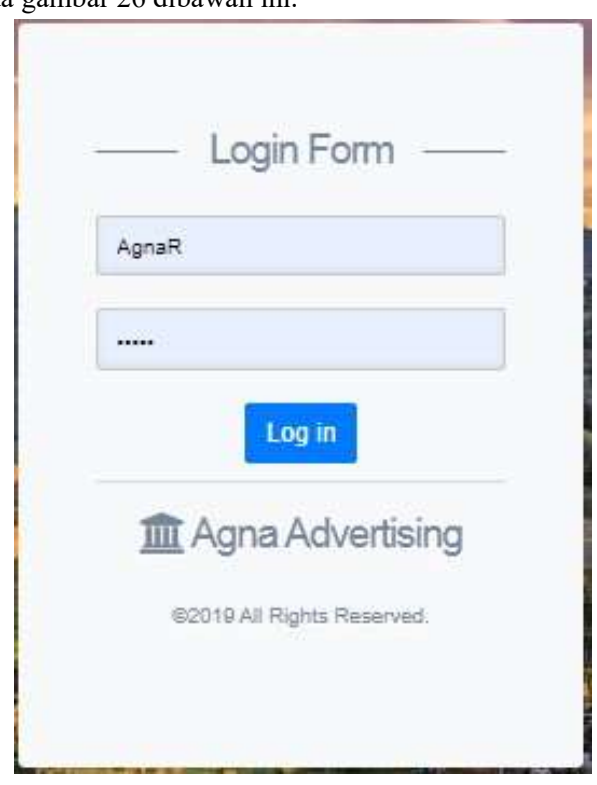

Gambar 26. Tampilan Halaman Login Admin

e. Tampilan Halaman Kelola Data User

Pada halaman kelola data user ini admin dapat melakukan tambah, hapus dan edit data yang dapat dilihat pada gambar 28 dibawah ini.

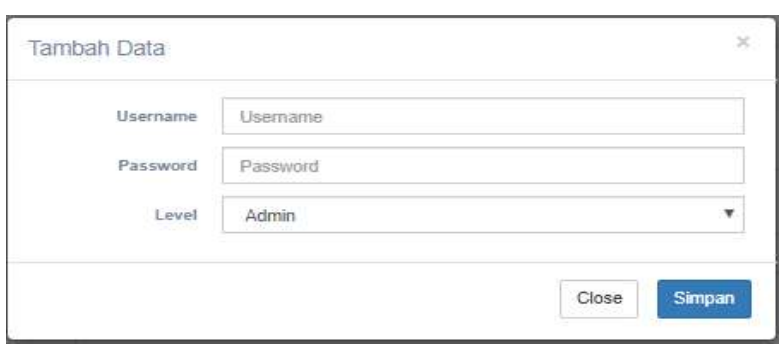

Gambar 28. Tampilan Halaman Kelola Data User 
Jurnal MediaTIK : Jurnal Media Pendidikan Teknik Informatika dan Komputer

Vol.3 No.1 (Januari 2020)

\section{f. Tampilan Halaman Kelola Produk}

Pada halaman kelola produk ini admin dapat mengelola data produk seperti mendmbahkan, mengedit dan menghapus data produk seperti gambar 29 dibawah ini.

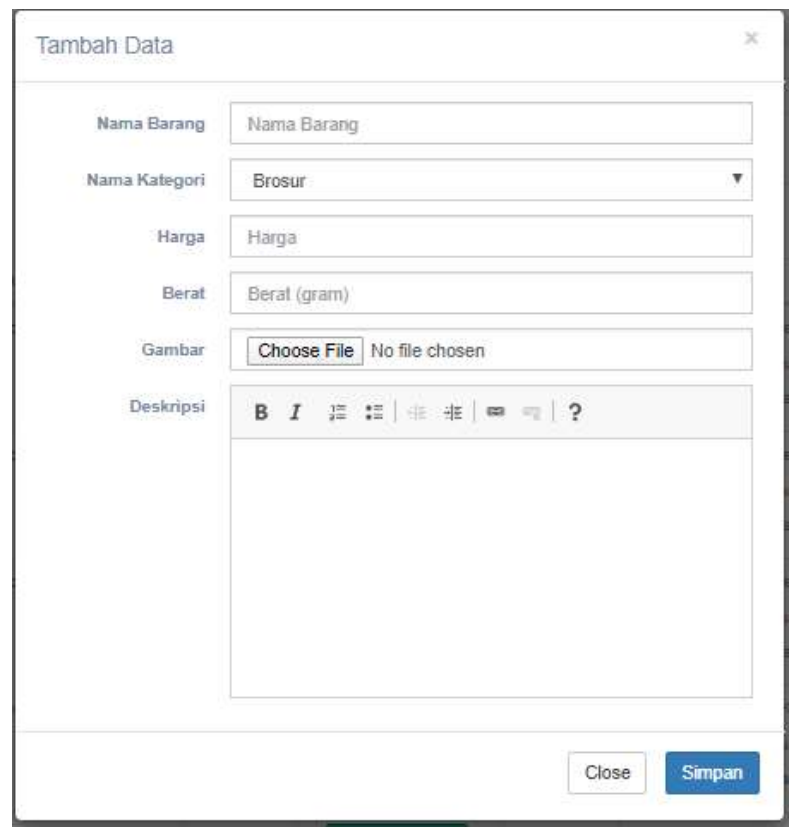

Gambar 29. Tampilan Halaman Kelola Produk

g. Tampilan Halaman Kelola Bahan Baku

Pada halaman kelola bahan baku admin dapat mengelola data bahan baku seperti tambah, ubah, hapus bahan baku yang dapat dilihat pada gabar 30 dibawah ini.

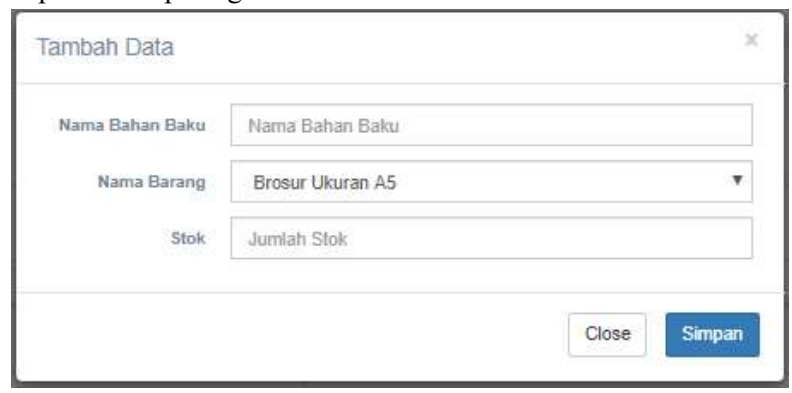

Gambar 30 Tampilan Halaman Kelola Bahan Baku h. Tampilan Halaman Chat

Pada halaman chat terdapat form pesan untuk melkukan chating antara admin dengan pelanggan yang dapat dilihat pada gambar 31 dibawah ini.

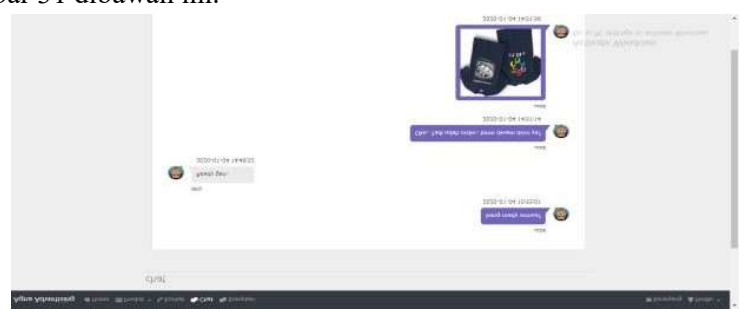

Gambar 31. Tampilan Halaman Chat

i. Tampilan Halaman Komplain

Pada halaman complain terdapat form pesan untuk pelanggan melakukan complain kepada admin yang dapat dilihat pada gambar 32 dibawah ini.

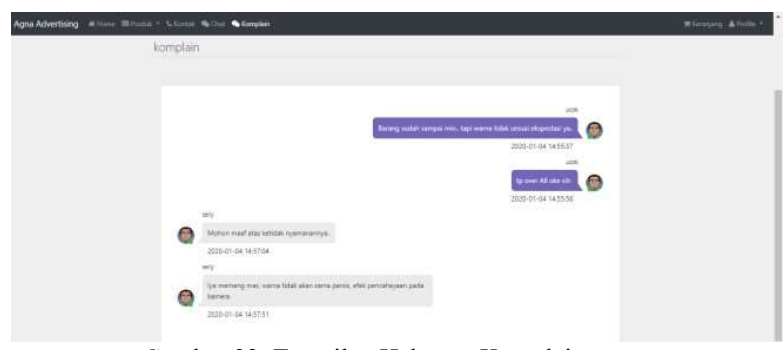

Gambar 32. Tampilan Halaman Komplain

j. Tampilan Halaman Laporan

Pada halaman Laporan terdapat data laporan pemesanan atau pembayaran yang dapat dicetak oleh admin. Seperti pada gambar 33 dibawah ini.

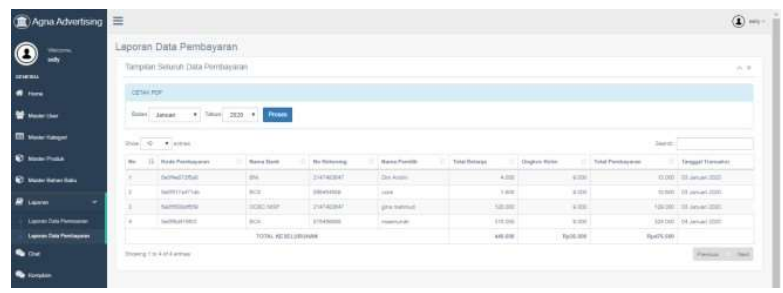

Gambar 33. Tampilan Halaman Laporann

\section{KESIMPULAN}

Setelah melalui beberapa tahapan yang telah dilakukan dalam membangun sistem informasi pengelolaan jasa pecetakan Agna Advertising berbasis web, maka dapat diambil kesimpulan sebagai berikut :

1. Dengan adanya sistem informasi ini dapat digunakan sebagai sumber informasi produk serta dapat memperluas jangkauan pemasaran produk jasa percetakan yang ditawarkan.

2. 2. Dengan sistem informasi ini dapat memberikan kemudahan bagi Pelanggan untuk dapat mencari informasi terkait produk dan jasa yang ditawarkan serta memudahkan 
konsumen dalam melakukan pesanan jasa percetakan tanpa harus mendatangi lokasinya.

3. Dengan adanya sistem informasi ini, pelanggan dapat melakukan pembayaran dimanapun dan kapanpun melalui transfer bank yang pelanggan miliki.

4. Sistem informasi ini juga dapat mendukung perusahaan untuk kearah yang lebih baik lagi dengan mengutamakan kepuasan pelanggan dengan adanya fitur komplain pelanggan pada sistem.

5. Dengan adanya sistem informasi ini dapat memberikan kemudahan bagi perusahaan untuk berinteraksi langsung dengan konsumen.

6. Sistem informasi ini juga memudahkan administrasi dalam melakukan kegiatan proses bisnis yang berhubungan dengan pengelolaan data seperti data pelanggan, pemesanan, pembayayaran, produk, kategori, bahan baku sampai dengan pembuatan laporan.

\section{DAFTAR PUSTAKA}

[1] Fauzi, R., Wibowo, S., \& Putri, D.Y., (2018). Perancangan Aplikasi Marketplace jasa Percetakan Berbasis Mobile. Jurnal Seminar Nasional Informatika, Sistem Informasi dan Keamanan Siber.

[2] Boone E. Louis. 2013. Pengantar Bisnis Kontemporer. Jakarta: Salemba Empat.

[3] Sugiyono, 2012. Metode Penelitian Kuantitaitf Kualitatif dan R\&D. Jakarta :Alfabet. Jurnal SWABUMI, Vol.5 Maret 2017,pp. 65-73.

[4] Susilo, M., Kurniati, R., \& Kasnawi, (2018). Rancangan Bangun Website Toko Online Menggunakan Metode Waterfall. Jurnal Seminar Nasional Informatika dan Teknologi Jaringan, 2, 98-105.

[5] Jogiyanto, 2005. Analisa dan Desain Sistem Informasi. Yogyakarta: Andi

[6] Kertahadi, 2007. Pengertian Sistem Informasi. Yogyakarta: Sistem Informasi

[7] Warsono, 2008. Pengertian Percetakan. Jakarta : erlangga

[8] Kotler dan keller, 2009. Menejemen pemasaran jilid 1 edisi ke 13. jakarta: erlangga.

[9] Holy Icun Yunarto. 2006. Business Concept Implumentation Series : In Sales And Distribution Management. Jakarta: PT. Elex Media Komputindo. 